
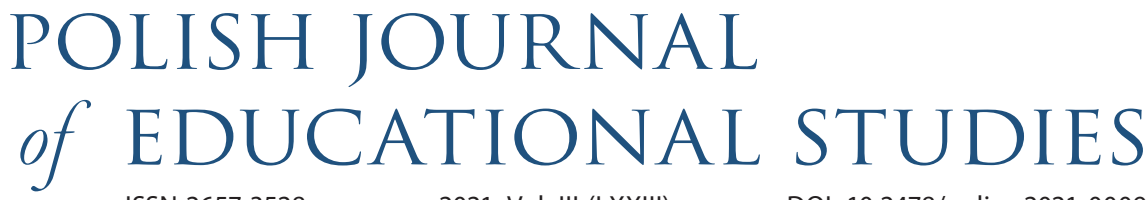

\title{
Remote Learning Under the Self-evaluation Microscope - Students' Opinions about Their Learning During the Covid-19 Pandemic
}

\author{
Monika Maciejewska ${ }^{1}$ and Katarzyna Białobrzeska²
}

\begin{abstract}
The impetus for the research presented in this article was the fact that universities have changed their mode of operation into distance learning as a result of the Covid-19 pandemic. This shift was universal and forced, and triggered significant changes in the way the classes were carried out. Therefore, questions arose about how the main actors of this scene, namely teachers and students, cope with the new educational reality. The course conducted by the author of this article, covering the fundamentals of evaluation, under which students each year accomplish evaluation research projects addressing important issues related to education at the Faculty, has provided an excellent opportunity to reflect in this regard. To this end, students prepared and accomplished self-evaluation projects, the subject of which was their functioning in the remote education mode. The analysis of the collected data made it possible to distinguish the elements of remote education, which are particularly important from the perspective of young people studying in new, atypical conditions.
\end{abstract}

\section{KEY WORDS:}

higher education, distance education, self-evaluation

The Covid-19 pandemic has evoked a global crisis that affects many areas of human activity. It can be said that our world, which has truly become a global village (McLu-

1 Faculty of Social Sciences, Institute of Pedagogical Sciences, University of Warmia and Mazury in Olsztyn, Poland E-MAIL: monika.maciejewska@uwm.edu.pI ORCID: 0000-0003-2945-0884

2 Faculty of Social Sciences, Department of Social Pedagogy and Educational Research Methodology, University of Warmia and Mazury in Olsztyn, Poland E-MAIL: katarzyna.bialobrzeska@uwm.edu.pl ORCID: 0000-0003-4105-2475 
han, 2021), has been afflicted with a hurricane turning the old order upside down and forcing us to intervene quickly and seek solutions to new problems. Education is one of the areas very clearly affected by the sudden change in the situation caused by the pandemic, or rather by the world-dominant way of dealing with the spread of the coronavirus, i.e. the introduction of social distancing laws. One of the steps taken in this regard was closing down institutions where people could get infected with the Covid-19 virus. Schools at all levels of education were among the first places to be deserted. Therefore, a search has begun for alternative methods of teaching, the dominant effect of which was the transfer of education to the media space, and especially to the area of the Internet and its tools. Similarly to the actions taken in the entire education system, universities have started to launch new paths of distance learning in an emergency mode. In the case of academic centers, it was probably simpler than in lower-level education, because the development of distance education has been in the focus of researchers' interest for many years (Kim, 2011; Lockee \& Moore, \& Burton 2001; Romaniuk, 2015; Mokwa-Tarnowska, 2017; Maleńczyk \& Gładysz, 2019). However, new solutions in this field were implemented slowly and treated rather as supplementary to the traditional education based on the master-student relationship. The mass, forced transition of universities to remote education has, however, provided invaluable experiences and made it possible to draw conclusions important for the development of modern academic didactics. Soon enough, after the first shock of changing the mode of education and the need to find technical solutions to emerging problems, scientists began to analyze the new situation. There was a reflection on its educational values, the challenges it is able to meet, but also the threats resulting from the thoughtless use of new projects made available on a massive scale.

The presented considerations inscribe into this trend of reflection. They are an attempt to look at the new situation from the students' perspective, who this time should be active participants of the introduced changes, and not only their passive recipients. This is due to two reasons. Firstly, the generation of current students is the generation of Internet "natives" (Prensky, 2001), also referred to as generation Z (Cantelmi, 2015) or generation C (Morbitzer, 2013; Friedrich et al., 2010), whose members move freely around the world of ICT tools and consider the Internet as their main source of knowledge. As a result, students often provide guidance regarding new media and their use for their teachers, clearly inscribing into the mode of transferring knowledge typical of prefigurative culture, described by Margaret Mead (2000). Secondly, such a radical, pandemic-triggered change in learning conditions in the education of students (young adults) may cause a confusing dilemma, described by J. Mezirow (1991) as an impulse for transformative learning. Therefore, watching young people enter a new mode of education is interesting both because of the cognitive values of these processes, as well as the practical possibilities of supporting them directly, or even strengthening them. 
The possibility of such a two-faceted action was fostered by the course conducted by the author of this article, covering the fundamentals of evaluation. As part of this course, students each year carry out evaluation research projects addressing important issues related to education at the Faculty. To this end, they prepared and accomplished self-evaluation projects, the subject of which was their functioning in the remote education mode. Thus, they had the opportunity to ask questions relevant to them regarding remote education and, simultaneously, could learn how to collect empirical data, enabling a wider insight into the situation. The analysis of the data collected in this way allowed identifying elements of remote education, which are particularly important from the perspective of young people studying in new, atypical conditions.

\section{Remote learning and its potential}

Today, remote education, distance learning, e-learning or e-education are terms that define the implementation of the education process through computers and IT networks in the spatial distance between the teacher and the student, and - in some cases - in time distance as well. However, the roots of distance education are sought in the first attempts to create correspondence courses undertaken as early as in the $18^{\text {th }}$ century. The direction and pace of its development have always been related to the technological advance in the field of information transfer. In the first half of the $20^{\text {th }}$ century, the most widely used transmitters included radio, television and newspapers. However, an undoubted breakthrough in the distance learning development was the advance in digital telecommunications, satellite and multimedia techniques, as well as computer systems and the Internet, which offered almost unlimited possibilities of communication. The use of the universality and polymorphism of new electronic media allowed e-learning to exceed the frameworks of traditional teaching and created a number of new learning opportunities (Winiarczyk \& Warzocha, 2021). The potential of this mode of operation is constantly increasing. Today, e-learning can be implemented deploying both synchronous activities (running as a real-time meeting, e.g. teleconference) and asynchronous activities (activities without time frames, with long-term access to training materials). Importantly, that this mode of education can have a global reach (e.g. by making the training available in the Internet) and significantly reduces the costs of educational services provided. A new resource of the remote education is also the possibility of conducting on-line courses on various mobile devices, such as tablets and smartphones. Moreover, this form of teaching can be used in many directions and at every stage of education as an element complementary to traditional teaching (blended learning), as an independent training program or as a method for updating knowledge (Krawczyk, 2020). 
The widespread use of e-learning in the pandemic-triggered social isolation has encouraged attempts to identify its real advantages and disadvantages perceived by its users (Winiarczyk \& Warzocha, 2021; Krawczyk, 2020). Its most frequently cited advantages include: better adaptation to the needs of students; the ability to learn at any time and place; learning at your own pace; the ability to quickly update and expand the training content; reduction of training costs; saving time; ease of training management and monitoring participants' progress; no restrictions on the number of trainees; making the learning process more attractive thanks to harnessing multimedia techniques, images and sounds; easy access to many sources of knowledge provided by the educational platform and the possibility of returning to them; and finally automation of the process of checking exams and generating reports. In contrast, the disadvantages of this method include: barriers in the IT infrastructure, including high cost of professional platforms, slow Internet connections, limited access to appropriate computer equipment or its complete absence, the possibility of computer or Internet failure, as well as insufficient IT skills of users; highly time-consuming process of developing materials for the e-learning process; problems with checking skills and participants' knowledge; problems with self-discipline and motivation to learn; lack of direct contact between the student and the teacher and fewer opportunities for interaction; a sense of loneliness; and motor absenteeism due to a too long work at the computer.

The urgent need for the universities to quickly adapt to remote learning in the first place exposed many shortcomings in the education process executed with the use of modern ICT tools, whereas the continuation of teaching tasks in the form of e-learning turned out to be a great technical and methodological challenge. Therefore, the process of shifting from the traditional role of a lecturer to the role of an e-teacher, whose task is to design e-lectures using e-tools, was complex and multi-faceted. Research on the functioning of Polish universities during the pandemic (Klimowicz, 2020) allowed determining the key stages of coping with the new situation by the academic community and to identify the related challenges. The first was the stage of "suspension and chaos" when the situation was treated as temporary and when attempts were made to tame it using the simplest IT technologies. Stage two "support [or lack thereof]" describes the period when attempts were undertaken to organize activities, choose educational platforms by universities, identify major technical problems and, prepare training for teachers. Mutual friendly help and the identification of problems faced by students were of great importance in this period. Entering the third stage, defined as the "new normality", unfortunately did not mean an effective solution to the problems, but was characterized by a change in the involvement of both teachers and students. Teaching methods began to be modified and new challenges were actively taken up. The issues of the mental well-being of students and academics were also 
clearly visible. In the fourth stage, the "overload" of teachers became prevailing, which was due to not only conducting classes in the new formula, but also to the excessively extensive reporting. The fifth stage involved "coming to terms with the situation and drawing conclusions". At this stage, voices are heard more and more often about the need to reform the teaching system of universities, or even to "reinvent it". Questions appear, then, on how to effectively exploit the movement that has emerged in strongly fossilized academic teaching. It is also worth paying attention to the voices of distance education researchers who demand a clear distinction between on-line education solutions developed for decades and the emergency distance learning introduced during the pandemic (Hodges et al., 2020). They also emphasize that the high quality achieved in remote education is the resultant of careful design and planning of educational activities using a systematic design model. This type of action will most likely be missing in fast and large-scale implementations. Contrary to classes planned from the beginning in the e-learning mode, remote classes in emergency situations are most often based on a temporary shift in the method of delivering instructions to students. The purpose of this activity is not to build a solid education system, but rather to provide temporary support in the learning process. While such temporary solutions cannot be denied a considerable amount of creativity in solving emerging problems, in fact they are oriented towards thinking about ways, methods and media in the context of rapidly changing needs and resource constraints, rather than towards laying the foundations for a stable and effective educational process and long-term solutions.

While considering the possibility of the most effective deployment of distance learning in academic education, the experiences related to its forced functioning at the time of the Covid-19 epidemic peak cannot be ignored. It is also worth considering the possibility of inviting students to joint activities in the search for new didactic solutions. As mentioned in the Introduction, they belong to the generation that is most able to appreciate the potential of e-learning and to give meaning to various elements that can increase its quality. This generation is described in various ways by researchers, but it is generally indicated that its representatives were born after 1990 and had contact with new media from their early childhood. From the perspective of the characteristics of this group of young people as contemporary students, it is worth looking at the description of generation C (Friedrich et al., 2010). Its representatives are continuously connected to the Internet, use social networks freely, and easily gather friends there. At the same time, they are able to create and process a large amount of information therein. They have personal digital devices used to constantly send text messages. They also definitely prefer communication through these devices. Sometimes they communicate simultaneously in multiple ways using text and video communicators, voice and data channels. This generation of students can simultaneously 
participate in university classes, browse the library of electronic teaching materials, compare their notes with those of other students, and take online exams. Due to their participation in virtual communities, the generation $C$ representatives are able to cross all geographical barriers (Friedrich et al., 2010) In other words, this generation can be characterized using a few English words starting with the letter C: connected, communicating, content-centric, computerized, celebritized, community-oriented, always clicking. Students from the generation of "digital natives" undoubtedly set new requirements for remote education. It is therefore worth establishing how they found themselves in the education system as a whole transferred into a virtual space.

\section{Self-evaluation in practice - methodological foundations of student projects}

The students' special ability to navigate in the world of the Internet and new media is an important, but not the only condition for effective distance learning. It is equally important, however, how they deal with the information that can be derived in this way and evaluate it reliably and realistically. In other words, it is vital whether they are able to think critically. These problems can be approached in a structured, insightful, and logical way. This refers to research patterns of searching for knowledge and solving problems that students can practice due to the implementation of applied research (including evaluation) into curriculum content accomplishment in the field of various subjects ${ }^{3}$. The preparation and implementation of self-evaluation projects by students inscribes into this mode of operation. In addition, it enables the simultaneous accomplishment of two goals: collecting data that allow to capture important moments in remote learning of students, and practical application of methodological knowledge to design and conduct a mini-project of an evaluation study ${ }^{4}$. The present work will focus on the analysis of data on students' coping with the conditions of remote education. On the other hand, the effects of students' work in the field of creating and implementing a research project will be presented in the form of basic methodological assumptions of the reconstructed research procedure.

Since evaluation research is heterogeneous in nature and can be embedded in various paradigms and methodological strategies, the leading assumptions of the constructivist evaluation model (Mertens, 2010), in which particular importance is

3 Such possibilities were described in, e.g., the article "Wykorzystanie etnografii wizualnej w procesie rozpoznawania problemów społecznych przez studentów" [“Use of ethnography in the process of identifying social problems by students"], Forum Pedagogiczne, 2/2020.

4 Small-scale research projects referred to as mini-projects were described by, i.e., P.I. Fusch, G.E. Fusch, \& L.R. Ness (2017). 
attached to the developmental aspects of the studied educational processes and to a deeper understanding of "school soul" or "university soul", were selected for the purposes of the course. The projects were embedded in the dialogical evaluation trend (Guba \& Lincoln, 1989), which, apart from research aspects, challenges the evaluators with tasks related to animating and facilitating the dialogue of the entities participating in it. The contents of the report are primarily expected to reveal the diverse ways in which people experience events. In turn, visual ethnography with the use of photography, used in recent years in Poland as part of evaluation research in education, was considered an interesting and effective method of project implementation (Nowotniak, 2012; Jewdokimow, 2012). The conducted research was in the form of self-evaluation (Simons, 1997), which means that the students were researchers of their own practice and made an attempt to determine the value of their own actions. The research was conducted on a group of 28 third-year students of the field of school pedagogy with cultural animation. Students worked in task groups, preparing introductions to the evaluation research project, and then on the forum of the group, directed discussions were held regarding the prepared photo reports. All activities were carried out in MS Teams. Discussions with the consent of the participants were recorded and transcribed.

The subject of the self-evaluation study was the functioning of students in the remote education mode. The aim set by the students - evaluators was to collect data on various aspects of their learning and operation during remote education (directly during classes and during their own work) and to draw conclusions that can be used in the process of optimizing remote teaching methods and techniques. An attempt was also undertaken to answer two key questions: How do students adapt to the remote study mode? What problems do students face when working remotely?

The projects were accomplished simultaneously in three separate task groups. Each group prepared a photo report, which was then presented on the forum and formed grounds for the directed discussion. The collected statements, transcribed and analyzed, served to construct the final reports. The empirical material presented below is a summary of the results obtained.

\section{Studying in the "times of the plague", meaning the reality of distance education from students' perspective}

An important value of the self-evaluation of activities undertaken as part of forced remote education is the independent work of students on its design and implementation. The perspective of the learning adolescents is clearly marked at the stage of asking key questions that cover the areas most important to them. Also, the next steps 
taken to accomplish the photo reports, i.e. defining the subject of the photos, selecting photos for the final presentation, and discussing the obtained material, are related to their individual choices. Therefore, the map of educational problems of students transferred to the world of e-learning outlined in this way can be considered fully original.

\section{New ways to study}

The analysis of the ways of students adaptation to the new conditions of studying has turned out to be the most noticeable area of self-evaluation. The photo reports generated extensive discussions in the task groups. They addressed the range of contents that the students wanted or were able to raise. The students noticed that the photo material showed not only what is happening in the foreground, but also the context of the situation. This thread appears in the statements of students: "We were brainstorming and thinking about what issues to raise; whether this would be issues of eating, cleaning, helping parents. There was a discussion, I remember, about what can be shown, how much can be shown (...) and also how to show this (...). To what extent can we get out of our comfort zone". Students coped with this dilemma in different ways. One way was to take a humorous approach to giving titles to the photos featured. The photo report showed that they were studying as being "hungry", "sloth", "fashionista", "diligent listener", "player", "fitness guy", "cook", and "sleepyhead". The group preparing this report was a bit skeptical about the activities undertaken by the students in parallel to the participation in remote classes. Such a narrative, however, caused a great response in the discussion groups. Each of the students found themselves in one of the areas: "At the beginning, when I saw the photo of a student learning as "a cook", I found that it fits perfectly here with what I am doing. Since I started my studies, cooking has become my passion. And now I have a little more time for cooking when I am at home. " or in a few of them: "I find myself in the position of "sloth" and "cook", and thus also eat often in front of the computer. I also happened to do shopping during classes or pick up parcels from a parcel locker, because I ran out of time during the break between classes. Sometimes there is no choice, so I put my headphones on and leave the house trying to remember as much information as possible. "The activities that were illustrated in the reports as invariably coexisting with participation in on-line classes, included: cooking, driving a car, shopping, helping parents with household chores, caring for children, walking the dogs, multitasking, and resting. When asked about the place of conducting remote lectures outside the home, students indicated that they often spent their lectures in offices, health centers or shopping centers. They explained the emergence of such situations by the fact that they are often unable to 
reconcile their duties with private life, while the new media offer the possibility to log into classes from anywhere: "(...) I think it is such a mobility that I can re-play this lecture everywhere and I am always ticked in the system as "present at the lecture", no matter what I do." Thus, they indicate that often their ultimate goal is simply to leave information about their presence in the system.

While reflecting together on the issue of the effectiveness of learning in the new conditions, the students indicated both their pros and cons. They emphasized that some of the methods they use to accomplish classes result from the necessity of longterm sitting in front of the computer, which is more onerous than sitting at the desk. They are happy that "(...) on-line lectures give me the opportunity to listen and be on the move. In such a standard lecture, we just sat at the desk for an hour and a half and it seemed very long." There were also voices emphasizing the convenience and economy of distance learning: "The most important thing for me is convenience. The comfort of getting up a quarter of an hour before classes (...). Possibility to make and eat a meal during the lecture, doing minor housework, planning the day differently. It is also a big saving." In contrast, for other people, the necessity to make changes to the schedule of the day was quite difficult: "I remember sitting for a few hours on my calendar to attend both the exercises and the lectures. However, it taught me so much more control over what I do."

There were also doubts about the effects of "selling on both sides", which was heard in several statements. For example, the students agreed that "...the multiplicity of things we do actually diminishes the quality of doing each of these things. It is more such distracted attention than actually being able to do two things at a similar level at once." They also confirmed that for many of them, logging onto the platform during classes does not necessarily mean focusing on what is happening there: "Acting remotely, we just turn on the meeting and listen with half an ear and do something else with the other." There are also new possibilities of avoiding involvement: "Here I am convinced that you can hide somewhere, that we are only initials and nobody can see our faces. So you can hide somewhere in this crowd and keep quiet." In students' opinion, this may be due to a complete change in the context in which the education is provided. The stay at the university isolated students from the outside world and somehow forced certain activities: "(...) when we were at the lecture, we were at the lecture. We listened for an hour and a half, we did not do anything else. The whole day was devoted to it (...) And here we partly listen to these lectures and partly not." Now, students often have a hard time finding the right way to organize their work. Meaningful use of the opportunities offered by remote education is still a problem to be solved. Students often emphasize in their statements the sense of temporariness of action: "We are all in a very similar situation. This technology looks a bit like one big jar we are all thrown into and we really have to function in it somehow." According to 
students, the emergently introduced remote education causes great discomfort to all its participants, which in some way unites lecturers and learners in opposition to the problems that have arisen: "During remote classes, I noticed that we and the lecturers have similar problems. For example, someone could not start a presentation (...) and I saw we were in the same situation, just at two different sides. (...) It is obvious that we need to start working together. Thanks to this, the relationship just tightened, we all got closer to each other. (...) You could say that we have a common enemy and that is what unites us. (...) The fact that we are in an uncomfortable situation made us all aware that we have to cope with it, so we try to help each other."

It is optimistic, however, that attempts have already appeared to improve the functioning in virtual educational reality. One of the student voices emphasizes this very aspect: "It is important for me that the lecturers, but also the students, have started looking for some alternatives to a simple lecture and writing down notes. We try to diversify the classes by using different websites, like Kahoot, or group tasks."

\section{Problems encountered by students in remote education}

The attempt to look at the problems faced by students during e-learning activities allowed to distinguish two main areas in which problems arise. The first is the area of technical problems, the second - the lack of direct relationships in the teaching-learning process that students are used to, and the need to replace them with relationships based on mediated communication.

Technical problems include mainly problems with properly efficient internet connections and the ability to efficiently operate educational platforms and mobile applications. Students repeatedly emphasized their concerns about the poor quality of Internet connections: "Such problems are probably the most related to the Internet. I had a situation twice where the Internet connection was breaking all day, because there was a problem with the network. And it was terrible, I could not make a contact, I simply could not do anything. (...) And it was terrible." These are situations beyond the control of both lecturers and students. However, it is difficult to accept them because they can also cause a sense of loss: "(...) on the one hand, I am already used to this lack of communication. But as a consequence, the lack of this Internet means that classes are temporarily missed while they are in progress, so (...) I am afraid that I may miss an important moment in a given lecture or some necessary information."

There was also a large group among the discussing students, who did not feel prepared to use remote education platforms and had problems with the proper preparation of the equipment. This is very well presented by the following statement: "I can honestly say that what I have learned from remote education is, apart from the 
knowledge of subjects, such a development in terms of technology. It is also the case that we are not the Internet generation yet, we were not born with a "telephone in hand". For us, entering this new learning system was not as easy as it might seem. We are often not that familiar with this subject as expected and we did not necessarily have a chance before to know how it all works, including e.g. how are videos recorded, how they can be re-made, and various other computer-related matters. How to fix a microphone or headphones or whatever. (...) we were on our own. It was not that some IT specialist was fixing it for us. Especially when we were running out of time when we needed to connect and something did not work, it had to be done quickly. It was also in these technological matters that we had to learn a lot." Thus, the assumption that students today have all the features of digital natives has turned out to be wrong in the case of some of them. It has turned out that young people also need IT support.

Issues related to building relationships that support the learning process are also complex. Students are unlikely to have any idea how to develop relationships in the virtual world. The statements are dominated by a sense of loss due to the lack of direct contact and the difficulty in finding the essence of studying: "For me, this is the distance learning that brings such a big chaos, it causes a lot of chaos in my life. I catch myself that I would go out somewhere (...) and I totally forget that I am a student." The necessity of organizing learning outside the university and in direct relationships also changes the perception of studying and the possibility of actually engaging in this process. "Studying means discovering, thinking, and engaging into discussions. Now it is not there, the level has dropped a bit as access to libraries was limited. Some classes, especially the practical ones, could not be carried out remotely. Studying has become an automated teaching of knowledge by lecturers. Students do not discover and study, but they only take ready-made information in a non-reflective way." Students also point to the lack of proper organization of classes and problems with time planning. They claim that some lecturers have not adapted their classes to the remote mode in any way, which is related to the inability to complete the entire study curriculum during lectures or exercises and causes the need for greater involvement of students in independent work. They also notice a general decrease in motivation to learn, which in turn causes difficulties in group work in which few people are willing to be active. Students also perceive problems that arise in the area of assessment, and above all, in appreciating the activity of individuals. They argue that, especially in the case of group work, lecturers lack an idea of how to take into account the individual commitment and workload involved in a given activity. One of the important remarks indicating the realities of the student world during the pandemic is showing the difficulty of drawing boundaries between private life and studying: "I get news about new assignments at any time. I have the impression that I am in the classroom around 
the clock, and by this means, that I had remote classes in every space I know, I cannot rest anywhere, because everything reminds me of work and study." This situation is stressful and increases the feeling of pressure.

Students also notice positive effects of distance learning that are important for them and usually related to the change of thinking about education and their active participation in learning processes. This is indicated by the following statement: "I have the impression that, contrary to common opinions, remote learning requires more organization and more skills from me. Whether this means technical knowledge and skills, or doing several things at once. We do many more projects and multimedia presentations than in the standard learning mode. And I also noticed that despite the fact that there are disadvantages, such as the lack of a study atmosphere, there are also positive sides."

\section{Conclusions}

Evaluation research in education is a type of applied research, the aim of which is to support the finding the solutions or making decisions important from the point of view of improving the quality of didactic processes. Their results do not entitle to formulate general conclusions. However, such research allows presenting a case study that enables a deeper recognition of the problem by setting it in a specific context of space and time. Final reports on evaluation studies usually also provide recommendations, but in the case of presenting self-evaluation as a good practice, it seems more appropriate to make a few reflections on the image of studying during crisis online education, which emerges from the research conducted by students.

The new educational conditions surprised the students. Some of them were not well prepared for the efficient use of platforms and applications necessary in online education. However, after the first phase of surprise and uncertainty, they start to cope better in the virtual world. For students, much more stressful than technical problems is the need to change their way of thinking about studying, their commitment to the learning process and the importance they give to different areas of their education. They mention that online education forces you to be more independent in terms of organizing your time. They also see problems that may arise in the multitasking situation. They also try to determine the value of remote classes that take place in different places and conditions. The new situation, therefore, raises the question of their responsibility for the results of their learning. Most of the statements are marked by a sense of the temporary nature of the situation, but there are also voices indicating that students see the need to engage in the search for other methods and forms of 
education that will make fuller use of the opportunities offered by online work. It is worth taking advantage of this emerging potential.

\section{References}

Cantelmi, T. (2015). Technopłynność. Człowiek w epoce Internetu: Technopłynny umysł. Wydawnictwo OO. Franciszkanów „Bratni Zew” Sp. z o.o.

Friedrich, R., Le Merle, M., Peterson, M., \& Koster, A. (2010). The Rise of Generation C. Implications for the world 2020. New York, USA: Booz \& Company Inc. https://adindex.ru/ files/44656/Rise_Of_Generation_C.pdf.

Fusch, P.I., Fusch, G.E., \& Ness L.R. (2017). How to Conduct a Mini-Ethnographic Case Study: A Guide for Novice Researchers. The Qualitative Report, 22(3), 923-941. https://nsuworks.nova.edu/tqr/vol22/iss3/16.

Guba, E., \& Lincoln, Y. (1989), Fourth Generation Evaluation. SAGE Publications, Inc.

Hodges, Ch., Moore, S., Lockee, B., Trust, T., \& Bond, A. (2020). The Difference Between Emergency Remote Teaching and Online Learning. Educause Review, 3. https:// er.educause.edu/articles/2020/3/the-difference-between-emergency-remote-teaching-and-online-learning.

Jewdokimow, M. (2012). Wykorzystanie metod wizualnych w ewaluacji wewnętrznej. Zarys problematyki. In G. Mazurkiewicz (Ed.), Jak być jeszcze lepszym? Ewaluacja w edukacji. Wydawnictwo Uniwersytetu Jagiellońskiego.

Kim, J. (2011). Developing an Instrument to Measure Social Presence in Distance Higher Education. British Journal of Educational Technology, 42(5), 763-777.

Klimowicz, M. (2020). Raport "Polskie uczelnie w czasie pandemii", przygotowany w ramach projektu "Społtech". https://centrumcyfrowe.pl/spoltech/polskie-uczelnie-w-czasiepandemii/.

Krawczyk, M. (2020). Nauczanie medycyny po pandemii. In Nauczanie po pandemii. Nowe pytania czy nowe odpowiedzi na stare pytania? Instytut Problemów Współczesnej Cywilizacji im. Marka Dietricha.

Lockee, B., Moore, M., \& Burton, J. (2001). Old Concerns with New Distance Education Research. EDUCAUSE Quarterly, 24(2), 60-68.

Maciejewska, M. (2020). Wykorzystanie etnografii wizualnej w procesie rozpoznawania problemów społecznych przez studentów. Forum Pedagogiczne, 2, 165-178.

Maleńczyk, I., \& Gładysz, B. (2019). Academic E-learning in Poland Results of a Diagnostic Survey. International Journal of Research in E-learning. IJREL, 5(1), 35-59.

McLuhan, M. (2021). Galaktyka Gutenberga. NCK.

Mead, M. (2000). Kulturai tożsamość:studium dystansu międzypokoleniowego. Wydawnictwo Naukowe PWN.

Mertens, D.M. (2010). Research and Evaluation in Education and Psychology. SAGE Publications, Inc.

Mezirow, J. (1991). Transformative Dimensions of Adult Learning. Jossey-Bass. 
Mokwa-Tarnowska, I. (2017). E-learning i blended learning w nauczaniu akademickim: zagadnienia metodyczne. Wydawnictwo Politechniki Gdańskiej.

Morbitzer, J. (2013). Ekspertyza dotycząca zmian w sposobie uczenia się osób urodzonych po 1990 r. ORE.

Nowotniak, J. (2012). Etnografa wizualna w badaniach i praktyce pedagogicznej. Oficyna Wydawnicza „Impuls".

Prensky, M. (2001). Digital Natives, Digital Immigrants. On the Horizon, 9(5), 1-15. http:// dx.doi.org/10.1108/10748120110424816.

Romaniuk, M.W. (2015). E-learning in College on the Example of Academy of Special Education. International Journal of Electronics and Telecommunications, 61(1), 25-29.

Simons, H. (1997). Samoewaluacja szkoły. In H. Mizerek (Ed.), Ewaluacja w szkole. Wybór tekstów. Wydawnictwo MG.

Winiarczyk., A., \& Warzocha, T. (2021). Edukacja zdalna w czasach pandemii COVID-19. Forum Oświatowe, 33(1), 61-76. 